\title{
INTRODUCTION TO THE VOLUME
}

\author{
LISAC.PIERACCINI
}

Roman writers were among the first to describe Etruscan cities, referring to the renowned duodecim populi of the Etruscans, ${ }^{1}$ a league of Twelve Peoples that met annually at the communal shrine of Fanum Voltumnae (Livy 4.23.5). Although a complete roster has not survived, many scholars agree that the following cities should be included in the group of twelve: ${ }^{2} \mathrm{Ar}$ retium (modern Arezzo; Etruscan name unknown); Kaiserie (Cerveteri); Clevsin (Chiusi); Curtun (Cortona); Persna (Perugia); Pupluna (Populonia); Veia (Veii); Tarchna (Tarquinia); Vetluna (Vetulonia); Velathri (Volterra); Velzna (Orvieto); and Velch (Vulci). Romans described the wealth and beauty of many Etruscan cities as well as the long sieges of seemingly impenetrable cities like Veii. The fame of Etruria, according to Greeks and Romans, was due to its people's vast trade relations, fertile lands, religious practices, and formidable cities. In effect, these cities were the earliest urban centers in ancient Italy. Looking at how they grew from hut settlements to wealthy and powerful urban centers is not only vital to understanding Etruscan history, culture, and society, but ancient Italy in general.

The more we examine the period between the ninth and seventh centuries BCE in Etruria, the more we recognize that Iron Age communities were literally the "bedrock" of Etruscan culture. Excavations at Caere, Veii, and Tarquinia, to cite just a few of the largest known Etruscan cities, clearly demonstrate an increase of wealth, trade, and social differentiation in the early Iron Age. It appears that this "proto-" or "semi-" urban period marked the transition from village to city for many Etruscan settlements. ${ }^{3}$ But how these Iron Age villages transformed from clusters of huts to civic centers with paved roads, gates, and temples, can only be studied on an individual basis - as Etruscan cities developed at their own pace and many variables determined such developments. Nevertheless, there are fundamental indicators of such transformation that apply to all Etruscan cities, for example, the location of a settlement (preferably on a high outcrop with natural defensive cliffs), access to water and trade routes, agricultural resources, mineral wealth, and specialized craft production - not to mention social factors as indicators of "state" such as religious ideas, language, kinship structures, and culture. ${ }^{4}$ As research continues to focus on the earliest phases of Etruscan communities, villages, and cities, we will gain more knowledge about Etruscan urbanism and its legacy throughout ancient Italy. But what is increasingly clear, as C. Riva has argued, is that Etruscan urbanism is an indigenous phenomenon and not a by-product of Greek urbanization. ${ }^{5}$

The present volume does not attempt to discuss theoretical issues related to urbanism in Etruria, but rather it strives to combine and analyze material culture from the urban and funerary landscape at Caere in order to better understand the city. The very word "city" implies an intrinsic marker for "civilization" and it is precisely this topic-namely, the civilization within the confines of the city - that this volume aims to explore. With this in mind, we are aware that the larger view of 
a "city" includes the hinterlands, ${ }^{6}$ and ports and areas outside the city and necropoleis proper, which are also examined here.

In the case of Caere, the tombs were the firstdiscovered indicators of the "city's" ancient past (see chapter 9, by Steingräber and chapter Io, by Naso, as well as chapter 25, by de Grummond). Urban sanctuaries, however, were among the first civic areas actually to be excavated, as best illustrated by the large votive deposit discovered in I826 near the Manganello sanctuary and temple. The unearthing of other rich votive deposits soon followed, including the Vignaccia deposit (although the temple has yet to be excavated; see Nagy, chapter 20) and the "Temple of Hera" in the Vigna Parrocchiale (see Bellelli, chapter 5, and de Grummond, chapter I3). Excavations of the Vigna Parrocchiale and Sant'Antonio no doubt have broadened the view of the urban and religious landscape at Caere and make it possible to discuss issues related to temple architecture and decoration (Lulof and Winter, chapter II), local workshops (see chapter I4, by Camporeale, as well as Rasmussen, chapter I5; Pieraccini, chapter I7; de Grummond, chapter I6; De Puma, chapter I8; Causey, chapter I9; Nagy, chapter 20; Roncalli, chapter 2I; Harari, chapter 22; and Ambrosini, chapter 23), and the sacred urban practices that form part of the social and religious indicators of a city. Inscriptions reveal a great deal about society, religion, ritual, and myth as understood at Caere (Wallace, chapter 4; and Bonfante, chapter 6).

Roads and gates were identified last century in addition to Caere's main civic center so that we are in a much better position to discuss the topographical aspects of the city as well as the total context of the Caeretan territory (Edlund-Berry, chapter 2). Excavations at the harbor installation at Pyrgi have in some ways transformed our thinking about the city on the plateau (Michetti, chapter 7). If we consider that cities should be analyzed as bodies of material, then Caere stands out as an impressive urban complex with abundant and varied material culture dating from the eighth to third centuries BCE (see especially Torelli, chapters I and 24, and Cerasuolo, chapter 3). Relatively few dated events have been recorded at Caere, but the incident of the stoning of Greek prisoners after the Battle of the Sar- dinian Sea ca. 540 BCE reveals details of history, health, and religious practices (Turfa, chapter 8).

The tombs have enabled us to trace the collective funerary ideology of Caere, and this information can now be combined with the results of excavations of the urban area, such as the sanctuaries, temples, and civic buildings (e.g., the elliptical building at the Vigna Parrocchiale and the hypogeum of Clepsina) to produce a more comprehensive and wide-ranging assessment of the city (see Bellelli, chapter 5). Combining the two areas greatly enlarges a body of knowledge that was, just a century ago, based almost exclusively on funerary evidence. The following chapters, therefore, present up-to-date analysis with new perspectives that allow for a fuller and deeper understanding of the urban fabric of ancient Caere.

\section{NOTES}

I. Some authors describe fifteen cities in the leaguequindecim populi Etruriae. See in general La lega etrusca dalla Dodecapoli ai Quindecim populi. Atti della Giornata di Studi, Chiusi, g ottobre 1999 (Pisa 200I).

2. Some of the Etruscan names are perennially under discussion. Cf. the lists in Bonfante and Bonfante 2002:222-223 and Haynes 2000:135. On Kaiserie see Torelli, chapter I and Wallace, chapter 4 of this volume.

3. Riva 20IO; Bartoloni 20I2; Leighton 2013; and Cerasuolo 2008.

4. Cunliffe and Osborne 2005.

5. Riva 2010:3-4.

6. For more on this, see Horden and Purcell 2000.

\section{B I B L I O G RAPHY}

Bartoloni, G. 20I2. "The Villanovan Culture: At the Beginning of Etruscan History." In Turfa, Etruscan World, 79-98.

Cerasuolo, O. 2008. "All'origine di Caere: Contributo alla conoscenza del processo formative protourbano in un settore dell'Etruria Meridionale." In Preistoria e Protostoria in Etruria, 683-694. Milan.

Cunliffe, B., and R. Osbourne, eds. 2005. Mediterranean Urbanization, 800-60o BC. Oxford.

Damgaard Andersen, H. 1997. "The Archaeological Evidence for the Origin and Development of the Etruscan City in the 7th to 6th Centuries BC." In Urbanization in the Mediterranean in the gth to 6th Centuries BC, ed. H. Damgaard Andersen et al. Acta Hyperborea 7:343-382. 
Horden, P., and N. Purcell. 200o. The Corrupting Sea: A Study of Mediterranean History. Oxford.

Leighton, R. 2013. "Urbanization in Southern Etruria from the Tenth to the Sixth Century вс: The Origins and Growth of Major Centers." In Turfa, Etruscan World, I34-150.

Riva, C. 2005. "The Culture of Urbanization in the Mediterranean c. 800-600." In Cunliffe and Osborne 2005:203-232. . 2010. The Urbanization of Etruria: Funerary Ritual and Social Change, 700-60o BC. New York.
. Forthcoming. "Connectivity beyond the Urban Centre in Central Italy." In Cambridge Prehistory of the Bronze and Iron Age Mediterranean, ed. A. B. Knapp and P. van Dommelen. New York.

Steingräber, S. 200I. "The Process of Urbanization of Etruscan Settlements from the Late Villanovan to the Late Archaic Period." EtrSt 8:7-33. 
THIS PAGE INTENTIONALLY LEFT BLANK 